Branislav Kovačević

Shan State Buddhist University, Mjanmar

branko@theravada.rs

DOI: $10.18485 /$ rit.2022.20.37.2
UDK: 241

Originalni naučni rad

Datum prijema: 27.10.2021.

\title{
SILENCE IN THERAVADA BUDDHISM AND ORTHODOX CHRISTIANITY: CASES OF THE BUDDHA AND EVAGRIUS OF PONTUS (PART II)
}

\begin{abstract}
Summary
The Buddha's refusal to answer some of the questions asked by countless interlocutors who parade in the Pali canon has provoked interpretations among Buddhist scholars to this day. This is how the well-known question of the „Buddha's silence“ arose. In this paper, I have tried to give a critical overview of these interpretations, as well as to problematize them by asking whether it was a matter of , silence " at all or a special strategy used for pedagogical purposes. Building on this and through the analysis of other similar examples from the Theravada literature, a specific „typology of silence“ has been developed, which sheds light on the different roles that silence plays in this form of Buddhism. This is how the ascetic silence, the silence according to the convention, the pedagogical silence and, in the end, the silence about the ultimate reality were identified. Of course, these types of use of silence and contrast with its opposite, sound, more precisely in the religious context with speech, are not typical only for Buddhism, but also for other religions. Therefore, in the continuation of the paper, the situation in Orthodox Christianity is analyzed through two examples. One is the reflection on the role of silence in the ascetic life of early Christians, which we find in the works of Evagrius of Pontus, one of the important early church fathers from the 4th century and one of the founders of the spiritual tradition within Eastern Christianity. The second is the hesychastic method, with its three phases: purification (katharsis), illumination (theoria) and deification (theosis), and the practice of ,,quietude "or mental prayer. All this made it possible to draw several parallels in the final part of the paper between the role of silence in the ascetic practice of Theravada Buddhism and early Orthodox Christianity.
\end{abstract}

Keywords: Buddhism, Orthodox Christianity, silence, Buddha, Evagrius of Pontus, hesychasm

\section{Orthodox Christian Use of Silence}

In the Christian world, Orthodox Christianity was following its own way in the Eastern part of the Roman Empire for centuries, even earlier than the formal separation from the West was officially proclaimed in the eleventh century. Thus, it didn't know much about Augustine, Thomas Aquinas nor scholasticism, pre- 
occupied with its own, quite an eventful history, including a schism with Rome, the fall of the Byzantine Empire, almost five centuries of Turkish oppression (except for the Russian Church), the emergence of national orthodox churches, two World Wars, persecution by communist regimes and, to some extent, secularization. In parallel with all this momentous historic events, Orthodox Christianity has been developing its own cultural, spiritual and liturgical forms, based on the heritage of the Egyptian and Syrian fathers. Among the spiritual ones, one is particularly relevant for our topic, and it is hesychasm.

\section{Hesychastic Silence}

The term "hesychasm", in its main meaning, that of silence and solitude, traces its origins back to the beginnings of monastic life in the $3^{\text {rd }}$ century. The word hesychia does occur frequently in the Sayings of the Desert Fathers and the label "hesychasts" has often been given in the Eastern Church to monks who, after spending long years in cenobitic monasteries and leading communal life, decided to live entirely or almost alone, giving themselves to contemplation and prayer.

Conceived in the deserts of Egypt and Sinai Peninsula, the movement would fully emerge much later, in the $14^{\text {th }}$ century at Mt. Athos in Greece and become the centerpiece of the Orthodox spirituality. Further enriched with the help of the Russian theological thought, it is very much alive in the Christian East even today. Its practical part consists of the full-fledged program, succinctly described in the writings of St Gregory of Sinai (1260-1346). According to him, the initial step was developing five virtues, as a foundation on which to build: silence, self-control, vigilance, humility and patience. They are said to affect and consolidate each other. Equipped with these, a monk should further engage oneself into three practices "blessed by God": psalmody, prayer and reading. In case of those of poor physical strength, manual work was recommended too. Here is how this engagement looks like:

From early morning the hesychast must devote himself to the remembrance of God through prayer and stillness of heart, praying diligently in the first hour, reading in the second, chanting psalms in the third, praying in the fourth, reading in the fifth, chanting psalms in the sixth, praying in the seventh, reading in the eighth, chanting psalms in the ninth, eating in the tenth, sleeping in the eleventh, if need be, and reciting vespers in the twelfth hour. Thus fruitfully spending the course of the day he gains God's blessings. ${ }^{1}$

1 Philokalia, Vol IV, p. 233. 
Through a diligent practice a monk gradually discovers that one comes to self-knowledge and knowledge of God through attentiveness and watchfulness (nepsis), but also through stillness and silence (hesychia). Therefore, the hesychastic movement that by time emerged inside Orthodox Christianity put these two qualities in the forefront of the ascetic practice. In that respect, we could here identify an example of ascetic silence we discussed previously.

Hesychastic program also encompassed utilization of various psycho-physical practices, involving so-called Jesus Prayer, but also breathing and physical postures, based on the ancient Judeo-Christian conviction that human beings are created as a unity of body and spirit, put into conflict with each other only by sin itself. Besides Evagrius of Pontus, who is considered one of forefathers of the hesychastic movement, its theoretical underpinnings could also be found in the apophaticism or "negative theology" of such figures as St. Gregory of Nyssa and Dionysius the Areopagite. Their emphasis on saying what God is not was intended to a quieting of thought and a direct experience of God.

Thus, it seems that by the $7^{\text {th }}$ century the word hesychia as a technical term was well established in the confines of the patristic literature, since John Climacus devoted a whole chapter to it in his famous treatise The Ladder of Divine Ascent. But already in the Sayings of a Desert Fathers there are ample references to the importance of a silence and the internal state of hesychia, similar to this short story which illustrates the use of pedagogical silence:

Abba Theophilus, the archbishop, came to Scetis one day. The brethren who were assembled said to Abba Pambo, 'Say something to the archbishop, so that he may be edified'. The old man said to them, 'If he is not edified by my silence, he will not be edified by my speech'. ${ }^{2}$

Looking at the practice itself, one can discover three progressive steps on the path of a hesychast: catharsis (or purification), theoria (illumination, contemplation, being granted spiritual vision and insight), and theosis (divinization or union with God). The true spiritual goal of this internal journey consists of freeing the mind from its preoccupation with thoughts (logismoi) and desires, and restoring it to its true home in the heart, its natural equilibrium. Hesychastic prayer as a main vehicle of progress along the spiritual path is therefore often referred to as "the prayer of the heart", being concentrated on some simple word or sentence to be silently and constantly repeated. Usually these are the following phrases, pronounced

2 Ward (1984), p. 81. 
internally (or being merely a thought in various situations), slowly and with loving affection: "Lord have mercy" (Kyrie eleison), "Jesus", or in the more formal form of a prayer: "Lord Jesus Christ, Son of God, have mercy on me, a sinner". ${ }^{3}$

The effects of this practice are multiple and fundamental:

The name of Jesus, once it has become the center of our life, brings everything together. But let us not imagine that the invocation of the name is a "short-cut" that dispenses us from ascetic purification: The name of Jesus is itself an instrument of asceticism, a filter through which should pass only thoughts, words and acts compatible with the divine and living reality which this name symbolizes. The growth of the name in our soul implies a corresponding diminution of our separated self, a daily death to the self-centredness from which all sin is derived. ${ }^{4}$

\section{Evagrius of Pontus and approaching Immaterial immaterially}

Among the founders of the spiritual tradition within Eastern Christianity, including Hesychasm, the name of Evagrius of Pontus is particularly important for our topic. His approach to the religious life was at once theoretical and practical, with a great deal of attention placed on detailing the monk's journey toward God. By focusing our research on him, we are trying to distill his ideas related to the role of silence, solitude and stillness in the framework of the ascetic practice and hopefully be able to relate these findings to the examples from the Buddha's practice already presented.

Evagrius of Pontus (345-399), also known as Evagrius the Solitary, got his surname because he was a native of Pontus, a region in Asia Minor. His father was a bishop and young Evagrius was ordained and studied under the famous Saint Basil the Great in Caesarea Mazaca in Cappadocia. After Basil passed away in 379, he became a disciple of another great theologian, Gregory of Nazianzus. Under these Cappadocian fathers, Evagrius became a skilled exegete and when Gregory of Nazianzus moved to Constantinople to become a patriarch, Evagrius was invited along. There he participated in the Council of Constantinople (381), impressing many with his skill of debating. However, an affair with a married woman and its possible consequences soon forced Evagrius to leave the city and search for peace in a monastic life. Through Palestine, he found his way to the

3 Kurian (2011), p.

4 Gillet (1987), p. 96. 
Egyptian desert of the Cells (a colony of about six hundred anchorites), where he stayed until the end of his life 15 years later.

Evagrius was a prolific writer on asceticism, church history, biblical commentaries and letters, who deeply influenced Orthodox Christian spirituality through the works of those who further developed his ideas, like Maximos the Confessor, Dionysius the Areopagite or John of Klimakos. He is also considered a forerunner of the hesychast movement of later Byzantium. Today we have preserved some fourteen authentic works by Evagrius, among which the central position is occupied by the trilogy of the Praktikos, the Gnostikos, and the Kefalaia gnostika. In the first of these, consisting of short chapters, he has expounded his ascetic philosophy intended for less experienced monks. This experienced exegete of the soul knew too well that in the stillness of the desert, memories well up and a young monk can spend long hours wrestling with one's own thoughts and memories. The Praktikos is thus full of valuable instructions how to win in that battle. The second text is thematically a continuation of the previous work, but this time written for more experienced monks, as describes the practice in much more detail. Finally, in the third and the most important text, known also as the Problemata gnostika, Evagrius makes effort to fully develop his cosmological, anthropological and philosophical ideas. But he was also a master practitioner of the ascetic discipline and one of the famous teachers of the emerging discipline of contemplative prayer, a form of Christian meditation. Thus, he was among the first and the most successful Desert Fathers making an effort to connect ample fruits of Christian ascetic practice with the more metaphysical monk's itinerary leading him back to the Creator. ${ }^{5}$

In the framework of Orthodox soteriology, there is a specific goal of restoring our likeness to God, by putting the mind (nous) illumined by God in charge of the whole person. The way to this likeness to God or we might say to becoming the same with the Truth leads, unsurprisingly, from external silence of the Egyptian desert, the silence of absence as we labeled it, to the silence of presence, the internal one, the silence about the ultimate reality inherent to a peaceful mind and heart mirroring the eternal light while facing it. In those moments Evagrius was intrigued by a vision of formless light that he, and probably monks he knew, enjoyed at certain peak experiences occurring during prayer. Where did this light come from? Does it come out of the purified mind itself (which implies that the

5 In analyzing his texts, I'll rely on translations made by Robert E. Sinkewicz in his book Evagrius of Pontus: The Greek Ascetic Corpus, Oxford University Press, 2003 as well as by Father Theophanes (Constantine) at the site http://timiosprodromos4.blogspot.com/. 
mind's primordial nature is luminous) or the light comes from God, illuminating the mind much the same as the sun illuminates the moon? To find the answer Evagrius had to dive deeper into the ascetic silence.

As mentioned, Evagrius was probably the first among Desert Fathers who expounded a full system of ascetic training and this from the angle of the careful study of the functioning of the human mind. In his version, this study consisted of three phases. The first of these is self-purification, cultivating virtues and learning to combat "evil thoughts" (logismoi). His Praktikos elaborates on strategies applied in learning the nature of the different concepts and ideas with which the mind is constantly fed. In this way it becomes able to distinguish between various logismoi, demonic tempting thoughts, as well as to appreciate the beneficial ideas/perceptions (noèmata) suggested by angels or those that arise from neutral sense-perceptions. These efforts are awarded with the birth of passionless love and gift of apatheia. In this process, for Evagrius, dispassion (apatheia) or freedom from control by the passions is more than purity (agnoteta), but less than the full restoration of the likeness to God (kath'homoiosin). This kind of emotional integration of a person marks the end of the first phase of the process by which Christian praktikos, a spiritual aspirant, can mature into a gnostikos, a contemplative and teacher capable of true knowing (gnosis) of existent things, the inner meanings and purposes of God within creation and history. The main path to this goal is also identical to the already mentioned „dispassion of soul“, i.e. calming the mind, liberating from irrational drives, which in their extreme forms would today be called obsessions, compulsions or addictions.

The second phase consists of natural contemplation (theōria physikē) of the existing things, those without a mind (like rocks, plants and animals) and those who possess it (like men and angels). For Evagrius, contemplation is the natural activity of the mind, noticing God's presence in everything he had created, considering the whole world as a giant book written by God.

In the third phase an ascetic comes into the presence of and contemplates the God himself. This coming to the supreme form of gnosis may be taken as an intuitive knowledge attained through contemplation. It is not discursive theological knowledge in the sense of let say the Thomist theology of the Trinity, but knowledge of God in the philosophically intuitive and mystical sense. The Praktikos point out, right at the outset, that the ultimate goal of the path is an amalgam of the initial two phases:

"The Kingdom of the Heavens is dispassion of soul with true gnosis of existent things". ${ }^{6}$

6 Praktikos, 2. 
This pedagogy of the soul is complemented with a well-known scheme of eight thoughts (logismoi) that constitute the essence of all negative thoughts young monks tend to struggle with. In the Evagrian system these are thoughts of gluttony, lust, avarice, anger, sadness, accidie (listlessness), vainglory and pride. About two centuries later this list would be transformed by Pope Gregory I into the famous "seven deadly sins". Relying on the old Stoic idea of the limited scope of our power, Evagrius makes here a very interesting observation, which also resonates some Buddha's observations:

Whether all these thoughts trouble the soul or do not trouble the so$\mathrm{ul}$ is among those things which are not within our power; for these to persist or not to persist, or to set passions in motion or not to set in motion, is among those things which are within our power. ${ }^{7}$

It is interesting where Evagrius sees the main reason for arising of these passions in the ascetic's mind and if there is maybe something even more basic that initiates them. For him the first dilemma was whether passions are provoked by "conception" (ennoia, thought or notion in the mind) or the vice versa.

One must attend whether the conception sets the passions in motion; or the passions, the conception. For, on the one hand, some have the first opinion; on the other hand, some have the second opinion. ${ }^{8}$

And in the very next, 38th chapter he gives this decisive answer: "It is the nature of the passions to be set in motion by the senses". What he seems to claim here is a psychological insight that mind (nous), fed by impressions provided through senses, excites the passion. After seeing some pleasant food, the passion of gluttony may be aroused in me. But what about the very nature of that passion? Does it have some deeper source? Here Evagrius introduces another important point and again quite close to the Buddha, the centrality of (the illusion of) ego in producing all other mental disturbances:

The first of all the thoughts is the thought of self-love (philautia), after which the eight. ${ }^{9}$

Here the "eight" refers to eight passions/thoughts and self-love, a form of the false conception of self, is designated as the root cause of all the mental pollution that arise. To combat that pollution, in the case of Evagrius, the whole varie-

7 Praktikos, 6.

8 Praktikos, 37.

9 Skemmata, 53. 
ty of practical devices were prescribed. Reading, vigil and prayer are used to focus a wandering mind. Hunger, toil and the life in solitude contribute to cooling of an inflamed desire. Finally, "chanting of the psalms, long-suffering and mercy put a stop to temper aroused". "Mercy" here relates to giving alms, caring for the sick and comforting the afflicted ones. But among all these practices there is one above them all that Evagrius highly recommends. That is a constant prayer: "We have not been commanded to work, to keep vigil and to fast continually, but it has been legislated for us that we "pray unceasingly" " ${ }^{10}$ Here he follows what St. Paul had advised in his Epistle to the Romans (12:12).

Once an ascetic has achieved a certain measure of apatheia and virtue through observing, understanding and distancing himself from logismoi caused by passions (or demons), he is ready to enter the state of sincere prayer. What Evagrius consider a prayer differs from the usual understanding of the word as a petition or a praise to God. For him, it is a "contemplative prayer" or "wordless prayer", denoting more a state of mind, than an activity. Or defined in another way, as an internal journey, a long traveling without leaving a cell even for a moment:

"Prayer is the ascent of the mind towards God." 11

The Orthodox Christian theological tradition posited the mind (nous) as the highest element of the human person, as it actually represents the image of God within us, that which is most like its creator. Therefore, it is among our faculties the one most capable of knowing God. Relying on this line of reasoning, Evagrius acknowledges that for us as human beings nothing is more natural than praying: "Mind... is naturally constituted for prayer." ${ }^{12}$

The silent prayer is thus, according to Evagrius, the main road towards achieving the supreme goal of the ascetic's practice, the knowing of the God, or rather striving towards this goal and never fully achieving it. Also, being able to express that knowledge. And here we come to a long debated issue in the framework of Christian theology: In what respect if God knowable? Namely, even before Evagrius there was a well established line of reflections on the subject of the incomprehensible nature of God. It suffices to mention here Gregory of Nyssa and his Vita Moses or John Chrysostom's five sermons in Antioch, where he affirms that God "dwells in unapproachable light, whom no one has ever seen or can see". ${ }^{13}$ For Evagrius too, the invisible, immortal and incomprehensible God is

10 Gnostikos, 49.

11 Chapters on Prayer, 35. In Sinkewicz, p. 196.

12 Praktikos, 49. In Sinkewicz, p. 106.

131 Tim 6:16. 
above all form and even imagination. In his Exhortation to Monks he writes: "You could not comprehend the nature of God, not even if you flew on wings. God is incomprehensible, just as he is also our creator." 14

Therefore, the best those who intend to meditate on the nature of God could do is to empty their minds of all images or even hypotheses through a process of negation later formalized as an apophatic theology. In his Chapters on Prayer Evagrius gives the following instruction of this silencing the mind:

"When you pray do not form images of the divine within yourself, nor allow your mind to be impressed with any form, but approach the Immaterial immaterially and you will come to understanding". ${ }^{15}$

Approaching Immaterial immaterially as the highest experience of pure prayer. This traveling beyond forms and images into deeper dimensions of being, tells us Evagrius, brings us a vision of light without form. But it is also characterized by another parallel process, that of transformation of ascetic silence into a silence about the ultimate reality, as the "perfect silence alone proclaims Him". ${ }^{16}$

\section{The Life in Silence and Mind Purified}

As we have seen so far, there are noticeable similarities between Christian and Buddhist way of liberation observed from the point of view of Evagrius of Pontus and the Buddha, as well as between their use of silence as a skillful mean to this liberation. For both Evagrian and Buddhist way of self-purification and self-transformation, it takes acquiring a deep self-knowledge. "You want to know God? First know yourself", advises Evagrius. This knowledge is key to eradicating of all egocentric tendencies that torment us. The path goes through a series of steps building atop each other and minutely described by both teachers. These tendencies and everything else that diverts a mind from his goal was also analyzed into details in both traditions, creating a specific map of mind as a safe guide for spiritual explorers. Thus, Evagrius writes lengthily about his scheme of eight thoughts (logismoi) that are the essence of all negative lines of thinking, giving also advice on how to deal with each of them. This classification is similar to the Buddhist set of five hindrances (nivarana) as initial difficulties to be faced by an aspiring traveler along the Buddhist path. And as, for example, in the Mahā-As-

14 Sinkewicz (), p. 222.

15 Chapters on Prayer, 66. In Sinkewicz, p. 196.

16 Maximos the Confessor. Philokalia, Vol 2, p. 271. 
sapura Sutta (M 39), the Buddha also gives advice on how to overcome them. Therefore, and that is remarkable, both ways, Noble Eightfold Path and a path of a hesychast, stress the importance of studying functioning and also purification of the human mind. In both cases, it is recommended for this arduous process to be supported by external and internal silence. Time and again the Buddha recommends solitude of a "root of a tree" or an "empty hut" as a place most favorable for practice: "A bhikkhu delights in solitary meditation and takes delight in solitary meditation; he is devoted to internal serenity of mind, does not neglect meditation, possesses insight, and dwells in empty huts." ${ }^{17}$ At the same time, it comes as no surprise that Evagrius, like thousands of other hermits, found his "empty hut", an abundant source of ascetic silence, in the middle of Egyptian desert.

Indeed, I tell you, love voluntary exile, for it separates you from the circumstances of your own country and allows you to enjoy the unique benefit of practising stillness. Avoid stays in the city, persevere with your stay in the desert. ${ }^{18}$

Once the silent place was found, the long road of the practical life goes through well-defined phases. In the case of Evagrius, this meant growing in virtue (catharsis), the step which strongly correlates with the Buddhist training in $s \bar{l}$ $l a$. With the final goal of calming passions (apatheia), a state of mind quite similar to the one designated by the Buddhist term upekkha . This is achieved through cultivating stillness, also observing, understanding and distancing oneself from logismoi (negative thoughts like anger or pride) caused by passions (or demons).

A certain measure of apatheia allows a hesychast to enter the phase of contemplation, together with gradual acquiring of spiritual vision and insight (theoria). This is achieved by maintaining mind focused, the method which resembles Buddhist practice of samadhi, collecting the mind. There are in both traditions a number of objects and methods for a mind to stay focused and contemplative that overlap. For example, well know practice of maranasati has a counterpart mirrored in Evagrius' instructions: "Seated in your cell, gather together your mind, give heed to the day of your death, and then look at the dying of your body." ${ }^{19} \mathrm{But}$ in Christian system the greatest importance among different methods by far has a prayer. As with the states of mind starting with the second absorption (jhāna) and

17 Bodhi (1995), p. 308.

18 Foundations, 6. In Sinkewicz, p. 7.

19 Foundations, 9. In Sinkewicz, p. 9. 
up inside the system of Buddhist meditation, Evagrian prayer means complete silencing of thoughts and moving beyond words into wordless contemplation .

This similarity between two methods is underlined by the use of the word mind (nous) to describe what is in us that prays/meditates. Although for most of us today the word "mind" refers to the faculty of logical reasoning, in the Greek tradition, the nous was our intuitive side. It enables us to know and recognize the truth of things instantly, directly, without thinking, like instantly recognizing a beauty of a landscape or a friend's face in a city crowd. Likewise, for Evagrius, the way the mind silenced by sincere prayer knows God is not a matter of logic or reasoning; it is a direct seeing, direct intuition:

"For knowledge of God, one needs not a debater's soul, but a seer's soul." 20

With sincere and persistent practice, a mind starts to uncover its so far hidden potentials. As mentioned previously, Evagrius was puzzled with the experience of inner light while in deep contemplation. This reminds us that the Buddha was also describing pure mind, devoid of mental impurities, as luminous by its own nature:

Luminous, bhikkhus, is this mind, and it is freed from adventitious defilements. The instructed noble disciple understands this as it really is; therefore I say that for the instructed noble disciple there is development of the mind. ${ }^{21}$

How intriguing these experiences of light were for Evagrius and some of the monks he was surrounded with can be concluded on the basis of an episode described in the famous Palladius' Lausiac History. ${ }^{22}$ There he describes how Evagrius and Ammonius on one occasion visited John of Lycopolis, the famed "Seer of the Thebaid", to consult him on an urgent question concerning certain peak experiences during prayer: "whether the light comes out of the purified mind itself (implying that the mind's primordial nature is luminous) or whether the light comes from God, whose light in turn illuminates the mind, much as the sun illuminates the moon. John's answer was a bit coy: 'It is not in the power of human beings to explain it. Besides, the mind cannot be illuminated during prayer without the grace of God'." 23

Be it as it is, this shows us that the direction of the both ways of practice, Evagrian and Buddhist, was towards development and purification of the mind.

20 Kefalaia gnostika, IV, 90.

21 Bodhi (2012), p. 97.

22 Palladius, Historia Lausiaca, 35.

23 Harmless (2001), p. 512-513. 
As a result of such training, it will unfold its intrinsic luminosity and ultimately an ascetic arrives to the bliss of knowing and harmony with God (theosis) or knowing and harmony with the Truth (nibbāna), which in Buddhist vocabulary would be described as yathābhūtañānadassana. In the case of Christian ascetic this act is not possible without God's help, as he receives transforming grace from the Holy Spirit. Therefore, the entire process is described as a synergy of a human and divine forces. In the case of a Buddhist ascetic, he has got to essentially rely on himself only. In practice, that means emptying the mind of its usual discursive content and entering a place of silence and stillness (samādhi) or the state of hesychia.

As we have also already seen, the type of prayer highly recommended by Evagrius has another important quality. It is constant prayer. No doubts that here we can draw a parallel with the Buddhist practice of maintaining mindfulness in everything one does:

A bhikkhu is one who acts in full awareness when going forward and returning; who acts in full awareness when looking ahead and looking away; who acts in full awareness when flexing and extending his limbs; who acts in full awareness when wearing his robes and carrying his outer robe and bowl; who acts in full awareness when eating, drinking, consuming food, and tasting; who acts in full awareness when defecating and urinating; who acts in full awareness when walking, standing, sitting, falling asleep, waking up, talking, and keeping silent. ${ }^{24}$

The last step of the training is divinization or union with God, described by Evagrius as "true gnosis of existent things". This may correlate with liberating pañ̃a or the "seeing things as they are". Thus, there are a number of points of resemblance in Christian and Buddhist way of ennobling the mind/heart.

However, it should be also noticed that this resemblance is strongest at the beginning, in the domain of moral training, and the weakest with the last element of the triad, the final outcome of the ascetic interior quest. This is quite understandable, as the wisdom element, the final knowledge about the ultimate reality in these two paths directs us to two divergent directions, sometimes labelled as personalistic (in case of Orthodox Christianity) and impersonalistic mysticism (in case of Theravada Buddhism). One aims at meeting the God, Creator of this world, while the other one, completely negating the very existence of such Creator, brings us a vision of a universe as a totality of causally created, conditioned

24 Bodhi (1995), p. 147. Satipaț̣hāna Sutta (M 10). 
phenomena, but also of what is beyond that - unconditioned, nibbāna. In that respect, although those who arrived at the final point of these two paths, gnostikos and arahant, were so far traveling through a similar landscape, now they arrive at two essentially different points. And both of them claim of seeing directly the ultimate reality. What they saw, they hesitate to explicitly describe, supposedly for the similar reasons: "Do not speak about God inconsiderately and never define the Divinity. For definitions belong to created and composite beings". ${ }^{25}$ The Buddha would agree with this claim that Uncreated (asankara) is not possible to fully describe by what is created and composite, by language, that the experience of an awakening is not possible to fully translate into words:

"There is no measure of one who has gone out, (Upasiva," said the Blessed One).

"There is no means by which they might speak of him.

When all phenomena have been uprooted, all pathways of speech are also uprooted." 26

What gnostikos and arahant see, they understand in crucially different fashion. Christian mystic sees a universe, created with a certain goal in mind and geared toward this goal by a divine providence. He observes the universe with a purpose and willed toward that purpose by a force of God's forethought, at the same time incomprehensible, indescribable and irresistible. This picture is completely opposite to the Buddhist interpretation of the awakening experience, which lack recognition of any intentionality, pre-made plan in the world.

Let us at the end return to our classification of silence from the beginning of this text. After making a distinction between silence of absence, the outer silence of a desert, a forest or a cave, and silence of presence, which follows the end of a dialogue and represents a version of non-verbal communication, we further diversified the latter. Thus, four types of internal silence was postulated: (1) silence of social convention, (2) pedagogical silence, as a teaching tool, (3) ascetic silence, as a skillful mean, and (4) silence about the ultimate reality. So far we pointed out that in the context of spiritual practice in both religions there is a correlation between silence of absence as a necessary external condition for developing the silence of presence, internal peace and stillness. Another observation is that there is a relationship of hierarchy between these four types of silence, one

25 Skemmata, 20.

26 Bodhi (2017), p. 335. 
builds on top of another. Starting with the silence of convention as a form of social interaction, we come to the more confined area of relationship between a disciple and a teacher, who uses pedagogical silence to instruct his devotees when deems appropriate. Higher than that stands ascetic silence, as a powerful tool of avoiding all traps of careless words and letting go of deeply ingrained tendencies of verbal actions. Once it is firmly established in a mind of a silent sage, a muni, he is ready for a meeting with the ultimate reality. This meeting, as we've seen in both traditions of Buddhist and Christian asceticism, bring an experience that is expressed, in many instances, if not by metaphors or negative terms, that simply by silence. In that respect, silence or stillness, but of different degree, stands at the beginning and the end of the path of practice. It is thus an often hidden treasure of mind and heart which allow us, in words of Evagrius, to "live according to the law". ${ }^{27}$

Finally, it should be added that we started by setting a modest goal of comparing Buddhist and Orthodox Christian spiritual path through the use of silence as a useful tool of practice. But it seems obvious that this research uncovered much more points of convergence, which are not historical, not coming from direct contacts, but more psychological, being rather reflections of the basic structure of a human mind and the possibilities of its purification. Such a multitude of similarities certainly beg for further exploration. In that respect, this paper might be just a starting point for more comprehensive research in the future.

\section{Literature}

Bunge, Gabriel (1996): Earthen Vessels: The Practice of Personal Prayer according to the Patristic Tradition. San Francisco; Ignatius press.

Fanning Steven (2001): Mystics of the Christian Tradition. London: Routledge.

Father Theophanes (Constantine): The Evagrian Ascetical System. http://timiosprodromos2.blogspot.com/

Gillet, Lev (1987): The Jesus Prayer. Crestwood: St. Vladimir's Seminary Press.

Harmless, William; Fitzgerald, Raymond (2001): "The Sapphire Light of the Mind: The Skemmata of Evagrius Ponticus", Theological Studies, Vol. 62, pp. 488-529.

Hick, John (1993): Disputed Questions in Theology and the Philosophy of Religion. London: Macmillan Press.

Horner I. B. (1971): The Book of the Discipline - Vinaya-pitaka, Vol 4. London: Pali Text Society.

Karunadasa, Y. (2007): "The Unanswered Questions: Why Were They Unanswered? A Re-examination of the Textual Data", Pacific World, pp. 3-31.

27 Maxims, 13. 
Kurian George Thomas, Ed. (2011): The Encyclopedia of Christian Civilization. London: Blackwell Publishing.

Murti, T.R.V. (1955): The Central Philosophy of Buddhism. London: Allen \& Unwin.

Nagao, G. M. (1955): "The Silence of the Buddha and its Madhyamic Interpretation" in Studies in Indology and Buddhology. Presented in Honour of Professor Susumu Yamaguchi on the Occasion of his Sixtieth Birthday. G. M. Nagao and J. Nozawa eds. Kyoto: Hozokan, pp. 137-151.

Olivelle, Patrick (1998): The Early Upanishads: Annotated Text and Translation. Oxford: Oxford University Press.

Organ, Troy Wilson (1954): "The Silence of the Buddha", Philosophy East and West, Vol. 4, No. 2, pp. 125-140.

Panikkar, Raimundo (1989): The Silence of God: The Answer of the Buddha. Marykno11: Orbis Books.

Radhakrishnan, Sarvepalli (1946): Gautama the Buddha. Bombay: Hind Kitabs.

Sinkewicz, Robert (2006): Evagrius of Pontus: The Greek Ascetic Corpus. Oxford: University Press.

Steindl-Rast, David (2016): The Way of Silence: Engaging the Sacred in Daily Life. Cincinnati: Franciscan Media.

The Philokalia: The Complete Text (1983-1995), Vol I-IV. London: Faber and Faber.

Tilakaratne, Asanga (1993): Nirvana and Ineffability: A Study of the Buddhist Theory of Reality and Language. University of Kelaniya: Postgraduate Institute of Pali and Buddhist Studies.

Velez de Cea, Abraham (2004): "The silence of the Buddha and the questions about the Tathāgata after death", The Indian International Journal of Buddhist Studies, No. 5.

Walshe, Maurice (1987): The Long Discourses of the Buddha. Boston: Wisdom Publications.

Ward, Benedicta (1984): The Sayings of the Desert Fathers: The alphabetical collection. Kalamazoo: Cistercian Publications. 


\title{
Branislav Kovačević
}

Shan State Buddhist University, Mjanmar

branko@theravada.rs

\section{TIŠINA U THERAVADA BUDIZMU I PRAVOSLAVNOM HRIŠĆANSTVU: PRIMERI BUDE I EVAGRIJA PONTSKOG}

\begin{abstract}
Rezime
Budino odbijanje da odgovori na neka od pitanja koja su mu postavljali bezbrojni sagovornici koji defiluju u Pali kanonu izazvalo je niz interpretacija među proučavaocima budizma sve do danas. Tako je nastalo poznato pitanje „Budinog ćutanja“. U ovom radu sam pokušao da dam kritički pregled tih tumačenja, kao i da ih problematizujem pitanjem da li se tu uopšte radilo o ,ćutanju “ ili o naročitoj strategiji korišćenoj u pedagoške svrhe. Nadovezujući se na to i kroz analizu drugih sličnih primera iz theravada literature, razvijena je specifična „tipologija tišine“, koja osvetljava različite uloge koje tišina igra u ovoj formi budizma. Tako je identifikovana asketska tišina, tišina po konvenciji, pedagoška i, na kraju, tišina o krajnjoj stvarnosti. Naravno, ovakvi vidovi korišćenje tišine i kontrastiranja sa njenom suprotnošću, zvukom, tačnije u religijskom kontekstu sa govorom, nisu tipični samo za budizam, već i za druge religije. Zato se u nastavku rada analizira situacija u pravoslavnom hrišćanstvu i to kroz dva primera. Jedan je promišljanje uloge tišine u asketskom životu ranih hrišćana, koja nalazimo u delima Evagrija Pontskog, jednog od važnih ranih crkvenih otaca iz IV veka i jednog od utemeljitelja duhovne tradicije unutar istočnog hrišćanstva. Drugi je isihastički pokret, sa njegove tri faze: pročišćenje (katharsis), iluminacija (theoria) i oboženje (theosis) i praksom ,tihovanja" ili umne molitve. Sve to je omogućilo da se u završnom delu rada povuče nekoliko paralela između uloge tišine $u$ asketskoj praksi theravada budizma i ranog pravoslavnog hrišćanstva.
\end{abstract}

Ključne reči: budizam, pravoslavno hrišćanstvo, tišina, Buda, Evagrije Pontski, isihazam. 